\title{
A Political Economy of News Media in the People's Republic of China
}

\author{
Jesse Owen Hearns-Branaman \\ Institute of Communication Studies \\ University of Leeds, UK
}

Keywords: Chinese news media, Chomsky, Herman, political economy, Propaganda Model, transitioning media systems

\begin{abstract}
This article analyses the political economy of news media production in the People's Republic of China (PRC) using Herman and Chomsky's Propaganda Model. This method contains two aspects: (1) an examination of the effects that a capitalist base has on news media in the transitioning system of the PRC, and (2) a study of the utility of the Propaganda Model's dimensions for use in comparative media research. The article finds that the differing political systems of the USA and the PRC do not lead to completely different media systems. The largest differences are found to be only in the civil society sphere and in the repression of PRC journalists. The capitalist base of the media system, however, causes many commonalities, such as pro-capitalist ideology, the influence of advertisers and constraints on sourcing, while a transition towards a US-style system, in professionalization, corporatization, secularization and conglomeratization, can be found in its embryonic stages.
\end{abstract}

At the beginning of the twenty-first century the People's Republic of China (PRC) is securing its position as an important global player. This country's entry into the World Trade Organization (WTO) in 2001, along with its massive economic growth, has signalled a major paradigm shift in the balance of global economic and political power. This economic growth is largely due to the increasing influence of capitalist institutions and ways of governance brought into the PRC since its opening up in the late 1970s, an influence heavily felt in the PRC's unique and conflicted news media system. Many observers say that the PRC's political structure is not experiencing a concurrent change toward democracy along with its economic development, others would point out that the 'revolutionary' political reforms for post-communist countries (especially in Eastern Europe) are marked by a continuation of the previous political elites, now operating in a capitalist economy, and that a transition to democracy is not inevitable (Sparks, 2008). Essential to this debate, and to any research on transitioning countries, is analysis of the functioning of their respective news media system; and the growing economic influence of the PRC, the influence of its news media on its population

Westminster Papers in Communication and Culture (C) 2009 (University of Westminster, London), Vol. 6(2): 119-143. ISSN 1744-6708 (Print); 1744-6716 (Online) 
and world news flows in general is an essential topic for research.

This study has two major goals. The first is an attempt to analyse the current political economy of the PRC's news media system by using the five filters of Herman and Chomsky's (1988) Propaganda Model (PM), first developed to describe media production in the USA. My second goal is to examine usage of the PM filters, ones firmly grounded in a long tradition of political-economic research, to be used as the terms of analysis for future comparative research in other media systems. How closely these categories 'fit' into the US model will perhaps give us a deeper understanding of the nature of such media systems' transition and the trajectories that such transitions could take. The PM consists of several economically determinant 'filters' (advertising, size, ownership, profit structure, sourcing patterns), one socio-cultural filter (flak-producing organizations) and one ideological filter (dominant ideology).

It should be stated that this study is not attempting to fit the PRC to a specific media model, as has been attempted for other countries using Hallin and Mancini's (2004) 'Three Models'. In that study, four dimensions were drawn up in order to place the media systems of North America and Western Europe into three generally cohesive models. The political-economic and geographical specificity of that study makes it far more valuable than previous efforts to include all media systems in the world, especially that of Siebert et al. (1956). The cost, however, is that it renders these models highly incompatible with the media systems of former communist states, especially one-party states such as the PRC. For the purposes of this study, the five filters of the PM will be unpacked and used as dimensions for the analysis of the PRC's media system.

The PM's analytic dimensions differ in several important ways from those put forward by Hallin and Mancini (2004). The focus is less on the influence of 'journalistic professionalism' and 'mass circulation press'; instead it includes issues of ideology, ${ }^{1}$ an area not important to the 'Three Models' study. It also keeps in mind the influence of Hallin and Mancini's 'political parallelism' and 'state intervention' concepts, contained in the Ownership Filter. This potentially gives the PM its strength in looking at transitioning media systems, such as in the PRC, by putting more focus on ideology in general, and the hegemony of global capitalist ideology in particular, which is gaining influence with the further solidification of the global economy and its expansion into the previous no-go regions of post-communist countries.

\footnotetext{
${ }^{1}$ Under which, it could be argued, journalistic professionalism is subsumed, in that it operates under dominant cultural-ideological norms.
} 
Before this study begins, a historical grounding of PRC news media needs to take place. All previous systems of news media production in China have been borrowed almost wholly from the West, be it the imperialist capitalism-based media system ejected from the mainland after 1949 or the Marxist-Leninist system used by the Chinese Communist Party (CCP), with minor alterations, since its inception in the 1920s. The CCP initially used news media for communist propaganda, but that function has since gone through two modifications: in the mid 1940s, when news media were used to legitimate the CCP's conquest of most of China; and since the 1970s (especially after 1992), to explain the nature of the transition towards a market economy (Chan, 2003; Lynch, 1999; Pei, 1994; Zhao, 1998, 4-51). The post-1970s period has seen all Chinese news media become completely financially independent from the government, apart from a financially inconsequential subsidy (Redl and Simons, 2002, 21), while remaining an integral part of the functioning of the government and adherence with the Communist Party's line.

This study will reveal many aspects of the current situation in the PRC, both universal and unique. The filters on news media production caused by the ownership structures of PRC media units are quite similar to those in the USA, with several important differences discussed below. The filters of sourcing and the influence of advertisers help illuminate issues that we might consider 'universal' for commercial media production, while the lack of formal flak-producing organizations in the PRC will indicate the different way in which that aspect of civic society operates. The dominant ideology in the PRC in many ways copies that of the USA, with some reservations about the different process of ideology formation.

\section{Size, Ownership and Profit Motive}

The first filter, drawing largely from the work of Curran and Seaton (e.g. 1985; 2009) and Bagdikian (2004), presented concerns as to the limitations on ownership caused by the 'large size of investment' needed to start a new news media business, one that 'was applicable a century or more ago' (Herman and Chomsky, 1988 , 4). It also deals with the power that large media companies have in comparison to smaller, less well-funded ones, as well as the effects that the source of funding for the news media outlet (public subscriptions vs. private advertisements vs. government or political sponsorship) has on whose interests it serves.

Lee points out that in advanced capitalist countries, such as the USA, 'state control of the media is more invisible and benign' $(2000,134)$, especially compared to the PRC where government censorship is more open. Modern capitalist society's 'absence of direct coercion', that is, compared to threatened violence by a 
monarch or autocrat, is needed due to the divorce of 'the central organizing economic structure' from said 'means of violence that has always been the prerogative of the state' (Heilbroner, 1985, 90), and is instead replaced by 'the generalized pressure of market forces' (ibid., 98). In the PRC we find 'power exerted by both the state and the market' at the same time, which 'can destabilize media practices' by making 'media workers deal with intense contradiction by improvising', causing 'organizational norms [to be] fuzzy' (Ma, 2000, 23; see also Pan, 2000). Delving into those 'fuzzy' areas has only led to more tentative conclusions, therefore a fuller examination of the more grounded political economy of media ownership could provide a stronger theoretical foundation for future research, as well as illuminate the directions that PRC media development could take in comparison with that of US and UK media.

For this section I will examine the filter concerning how the structure of a media company itself can affect news media production. The major point of contention in this regard is that the PRC news media system, and indeed all print and broadcast media units, are owned and controlled by the government, as they are organs of either the national or provincial Propaganda and Education System, which is under direct control of the Party Affairs Bureau (Liberthal, 1995, 192-9) and are still considered to be political units, not commercial enterprises (Chan, $2003,160)$, despite their lack of financial support by the government. The profit motive of PRC media is not paramount, but it is still heavily influential, for if the media unit cannot attract an audience to sell to its advertisers it will cease to exist. This causes many contradictions, which will be examined after an analysis of the ownership structures of PRC news media.

\section{Public vs. Private Ownership}

The 'Soviet-Communism' theory of the press takes media to be instrumental in maintaining the 'socialist system' and 'the dictatorship of the party' (Siebert et al., 1956, 7), and as 'instruments of unity ... propaganda and agitation' (ibid., 121). This may have been the case once in the PRC, and this rationale still forms the basis for why media units are part of the government, but the function media performs has moved partially towards the 'Authoritarian' model on one hand ('to support and advance the policies of the government in power' [ibid., 7]) and 'Libertarian' on the other ('to inform, entertain, sell' [ibid.]). Similarly, if using Williams' (1968, 123-9) concepts of Authoritarian, Paternal and Commercial media systems, the PRC would fit into all three to varying degrees: PRC elites use the media to legitimate their rule (authoritarian), guide the population (paternal) and sell consumer products (commercial), and perform all three functions simultaneously. The presence of such mixed media systems has caused these previous classification schemes to be of limited usage in the post-USSR era. 
The effects of who exactly owns the news media unit, and what purposes it serves for them, is only made more complex and conflicted by looking at the situation in the PRC. In theory, news media producers owned by the government, such as Voice of America in the USA, or semi-independent, but answerable to and largely dependent on the government for its revenue stream, such as BBC News in the $\mathrm{UK}$, are differentiated because they have a special function in society and do not heed market forces. For instance, in the UK the licence fee sponsored BBC was set up to 'act for the preservation of certain social and cultural standards' and continues to be seen as carrying out that role by many elites (Marwick, 2003, 70). While there was no such large-scale public broadcaster in the USA, certain vague guidelines were still set up to make sure a certain portion of media content is educational, and, occasionally, that news reporting should be 'fair'. The view in the PRC that the audience is 'child-like, uneducated and in need of careful nurturing, protection and guidance' (Latham, 2001, 90) is similar to the BBC's paternalistic functions, but as PRC media are under control of market forces, discrete classification along these lines is difficult.

Another dimension to consider is the 'political parallelism' of Hallin and Mancini (2004), indicating the partisan affiliation of a news media company. News media in the USA were highly partisan until the electoral reforms of the 1890s, when journalists began to view the establishment of non-partisan objectivity norms as 'a natural and progressive ideology for an aspiring occupational group at a moment when science was god' (Schudson, 2008, 30-33). While public media, such as the $\mathrm{BBC}$, are not viewed in partisan terms, unlike privately owned British newspapers, the US news media now prides itself on its secular nature and routinely derides PRC news media as 'state-run media' or 'a government mouthpiece'. The other difference is that conflicts within the CCP elites, especially since 1989, are often resolved internally and out of the spotlight of the public and the media (e.g. Shirk, 2007), whereas in multi-party democracies such arguments are frequently quite public and often performed with the media in mind. The absence or presence of partisan political debate in mass media does not necessarily mean more or less pluralism of opinion, nor that the elites have actual, fundamental political differences.

In both modes of control the majority of people are excluded from media production, which is in the hands of the elites, as Williams (1968) pointed out, so focusing on that distinction may just be a distraction. One way to resolve this would be to view PRC media as commercial (income earned from advertising and subscriptions alone), partisan (with only one choice for their partisanship), and public (as in government-owned) all at the same time, and hence subject to the benefits and drawbacks of each of these. Of course, this makes for a more conflicted media atmosphere than in the USA or UK, for more conflicts arise when the audience has to be viewed concurrently as 'customers and consumers 
whose tastes and demands dictate media production and take priority in the competitive market atmosphere' (Latham, 2001, 90), potential trouble makers who need to be reminded why the CCP still holds legitimate power over the state, and as citizens needing protection and guidance. These contradictions will be dealt with later; first we will look at the ways in which news media and ownership are integrated into other economic sectors.

\section{Transnational, Vertical and Horizontal Integration}

In the PRC there is, at the time of writing, no foreign news media ownership and no ownership by international corporations that are horizontally and vertically integrated in their media ownership and/or potentially own other industries, such as energy or military armament production. The PRC is resisting such infiltration of their media system, and it was one of the only areas of market liberalization left out of the WTO agreements (Weber, 2003, 280), remaining closed 'to foreign ownership or operation under the WTO's "preferential treatment to developing countries" clause' (Lee, 2003, 13). Foreign investment in the media sector is limited to the information and communication technology (ICT) sectors (ibid.). There is also one joint-venture station, Phoenix TV, that can broadcast to parts of mainland China, operating out of Hong Kong with some capital investment from Rupert Murdoch's News Corp, but its infiltration is quite limited as of now. It is viewed as an experiment of sorts (Chan, 2003, 167-8), the results of which have yet to be translated into a concrete government policy.

The benefits of this lack of transnational integration are not clear. SrebernyMohammadi et al., among others, point out that mergers between US media companies and corporations involved in the military-industrial complex 'constrains the structural possibilities for media autonomy and for the diverse, even critical, public communications that are necessary for the maintenance and development of democratic societies' (1997: xx). In the PRC, where military industries and the media are both owned by the government, the potential for a similar conflict of interest is still quite great, however, and research on the comparative effects of global media, such as Herman and McChesney (1997), would benefit from looking at the PRC as a media system with no transnational integration, in order to further clarify this aspect.

The same can be said for vertical and horizontal integration within the PRC domestically. No media unit can purchase another media unit from a different governmental district, as that would be 'out their jurisdiction', as it were, just as they are (currently) barred from purchasing non-media companies. This feature makes the PRC news media more independent of corporate control that that in the USA, where a handful of multinational corporations control the vast majority of the media market, with the detrimental effects on media production that follow (Bagdikian, 2004, 27-54; McChesney, 2004, 57-97, 138-74). That being said, 
corporations and other governmental departments still do have a measure of passive influence on media units through the interaction of their respective elites, but this is not unique to the PRC and is better conceptualized by examining parallel interests and ideological congruence than the internal functioning of a forprofit corporation. The future regarding this situation is unclear, but as long as the media units remain profitable there is no reason for the PRC government to remove foreign and cross-governmental restriction on media ownership, as this would entail a massive reform of the system for minimal benefits.

\section{Centralization}

In contrast to the lack of media cross-ownership, there are aspects concerning the tiered nature of the system that have many similarities to the US situation. Herman and Chomsky $(1988,3)$ note how, since the Second World War, elite US media such as the New York Times and Washington Post, and national news television programmes, have had increasing power to set the agenda as to what makes an important news story. Their larger audiences and therefore larger revenue, can invest more in the production of news, making it easier for the local and regional news channels just to follow their lead. This places these elite media at the top of a tiered system, giving them greater credibility than regional or local media companies.

A similar tiered system exists in the PRC, as China Central Television, the People's Daily newspaper and the Xinhua news agency, run by the central government's propaganda arm, are unquestionably the agenda setters for political, international and domestic news highly influenced by the CCP. At the same time, serious political news is not marketable, and to deal with this the government has allowed party newspapers to launch 'affiliated metro newspapers', which are less directly controlled by the Party and can 'report' on more popular topics (sports, entertainment, fashion, etc.), in an effort to attract more advertisers and help their parent company $(\mathrm{He}, 2003,206)$. This situation gives the central government a much tighter control on the media agenda than in the US, but the differing extent of that control is debatable.

\section{Contradictions in Ownership and Profit Orientation}

The three limits on news media imposed by ownership structure mentioned above (they must serve the Party, the consumer's needs and the public's 'moral' needs) have created several contradictions unique to the PRC, and the study of those contradictions can lead to many interesting results, showing that, despite the structural differences, there are many similarities to media development in the US.

One effort to help media profitability has been the creation of media conglomerates since the mid 1990s: 'state policy is moving unmistakably toward further media consolidation' and is considered 'a hallmark of China's bureaucratic- 
authoritarian state capitalism at work' (Lee et al., 2006, 585). Press conglomerate 'managers rushed abroad to learn how Western conglomerates operate' because 'only by making their own press groups "bigger and stronger"' with 'sufficient economies of scale ... could they compete successfully with the Western media', an inevitability implied in the WTO agreements (ibid.). Many large newspapers have also established cooperative or otherwise jointly run websites to stake a claim on the internet and pool resources (Xin, 2002, 194). Media conglomerates and groups also help the government by 'serv[ing] as the means to control chaotic free competition and limit the proliferation of minor papers', thereby helping the Party maintain control but, at the same time, 'their economic independence can weaken political control and enhance editorial autonomy', thereby threatening the Party's control (Ma, 2000, 22). However, as mentioned above, the conglomerates are limited to their area of jurisdiction; while the Shenzhen Press Group can compete with nearby Hong Kong news media for audience and advertisers, for example, they are not permitted to purchase a Hong Kong newspaper, or vice versa.

Efforts at a secularization ${ }^{2}$ of the media, of a kind, have also taken place. $\mathrm{He}$ (2003) reports that 'most of the Party-run national and provincial newspapers' are now separating 'overtly propagandist content from the rest and confining it to designated areas, mostly the front page or "yao wen" (important news) sections', which can be compared to the "practice of separating opinion from facts in the Western media' (2003, 205). Also, the CCP is allowing the administrative boundary system to slowly break apart for the benefit of the non-Party press, allowing the non-Party press to be 'the first to ... enter the markets at the same and higher levels', thus helping to increase national competition (Chan, 2003, 163). Additionally, internet policy-making strategy is a comparatively open, for example the committee in charge of new media regulation is made up of scholars as well as officers, unlike most other committees which are just extensions of the Party (Zhang, 2006, 280-81).

Also, the professionalization of PRC media employees has been increasing in recent years. Along with introducing a new standardized accreditation system to obtain press cards (Zhao, 2008, 28-30), the old 'iron rice bowl' system of guaranteed employment, at least in the media sectors, has largely come to an end. Since the previous system suffered from great inefficiency and inflexibility, and 'market forces were gradually pulling the system toward a profit orientation' a new system for 'the hiring and firing of employees and the internal incentive system' was manifested (Lee et al., 2006, 588), thereby increasing productivity and the quality of work. This is accompanied by the introduction of venture capital, which is 'the hottest topic of discussion on professional publications and websites' (Pan and $\mathrm{Lu}, 2003,229$ ).

${ }^{2}$ By secular, I mean independent of direct partisan control. 
Redl and Simons (2002) believe that, as the WTO reforms continue to be implemented, TV producers, and potentially other news media units, will increasingly use stock listings and privatization measures to raise revenue, causing them to be legally responsible to their shareholders and 'duty bound to maximize commercial returns'; they posit the eventual necessity of removing media companies from the government's propaganda system and bureaucracy (ibid., 26). This concern for profit has also stimulated 'the relatively new phenomenon of accountable audience measuring tools' due to the advertising industry's increased demands for accurate statistics (ibid., 22). This, again, would bring the PRC system more in line with Western systems, where, 'for a television network, an audience gain or loss of one percentage point in the Nielsen ratings translates into a change in advertising revenue from $\$ 80$ to $\$ 100$ million a year, with some variation depending on measures of audience "quality" (Herman and Chomsky, 1988, 8), and could further complicate the CCP's political control over the press.

Another interesting aspect, which shares great similarities to developments in the US and UK, is the situation of news media dedicated to 'marginal' or 'workingclass' groups. Herman $(1992,74-6)$ believes that in the USA, business interests have become 'national interests' - the marginalized interests are those of women, farmers and labour, who constitute the majority of the population. Similarly, in the PRC newspapers such as the China Farmers' Daily, Workers' Daily and China Women's News can no longer help 'the social groups in their name's sake' because they need to attract a larger audience (Zhao, 2003, 51-2). The parallels with the weakening of working-class press in the 19th-century UK (e.g. Conboy, 2004; Curran and Seaton, 2009, 3-36) could point to a general tendency in capitalist development: in an advertising revenue-based system, groups without a high disposable income are not serviced by a media of their own, nor are their opinions taken as mainstream.

\section{Sourcing Filter}

The sourcing filter shows a great similarity in the USA and the PRC, and potentially in any capitalist-based media system. The dominance of government and other official sources in news media appears to be a journalism universal, for any media outlet would prefer the free and trustworthy information dispensed by an 'official' office over the other 'sources that are not prima facie credible' and are expensive to verify and corroborate (Herman and Chomsky, 1988, 19). This, in turn, spreads like a virus, for NGOs and businesses further copy and spread those governmentally generated 'facts' and figures into the private sector until they become 'common sense' and what largely constitutes 'the truth' (ibid.). In the PM framework this also includes news generated by businesses and corporate-funded think-tanks (see Herman, 1992, 12) as well as governmental reports. Also 
important are time and budgetary constraints that journalists face, physical barriers preventing access to sources, as well as the influence of the dominant ideology in the framing of the news stories when they are written.

A similar situation exists in the PRC at many levels. Xin shows that while 'market competition has succeeded in promoting diversity of content', it has yet to offer 'a challenge to official ideology', therefore the government is confident that 'the influence of the market can limit the potential for public debate and reinforce dominant ideologies' $(2002,193)$, forcing their sourcing techniques to follow the most cost-effective path. There is also an increasing relative openness of information in the PRC, such as evidenced by the coverage of recent events, such as the 2008 Wenchang earthquake in Sichuan Province and ethnic riots in 2008 and 2009. For instance, as Peter (2009) reports, the central government was logistically unable to limit news media's access to the earthquake zones, and thus rescinded its order barring coverage. Instead, only certain stories were banned from being covered (e.g. the shoddily constructed schools), and the inherent tragedy of the situation was relied on to frame the rest of the coverage (ibid.).

This shows a new media strategy for the CCP, moving away from direct censorship of potentially embarrassing situations, which gives a monopoly to rumours and foreign news coverage. For the recent Tibetan (2008) and Uyghur (2009) ethnic protests, the central government has been quick to put out its own spin on the events, including releasing selective footage of the destruction, featuring violence against the Han Chinese ethnic majority, and painting it as the work of internal 'splittists' being led by external sources. Instead of censoring such sensitive events completely, this strategy allows the PRC's spin to dominate within the PRC itself, as well as to compete with different interpretations in foreign media.

The potential liberating effects of internet and news media on sourcing opportunities has been limited by the PRC government as well. For example, the internet helped expose two major scandals in 2001, showing that the government was losing control over information management, for websites were 'not only the first to break the news' but then went on to undermine the official position (Chan, 2003, 170). The effect was not more opening up, but a change in law, stating that only websites 'who are licensed to report news are allowed to do so' (ibid.), effectively reining in the web. To explore this area more thoroughly I will examine two studies on PRC sourcing patterns and conduct a brief case study of my own.

\section{Sourcing Patterns in the PRC}

Horvit (2006) found that in the coverage of the beginning of the 2003 war in Iraq most international news agencies did not have a nationalistic bias in their use of sources, most preferring sources from US officials. The PRC's official news 
agency, Xinhua, was in fact the most 'balanced' (46 percent Western, 52 percent non-Western), while the average for the Western news agencies was 60 percent vs 36 percent (ibid., 438). Despite the PRC government's anti-war stance, Xinhua's reporting was far more neutral, for example quoting equally both Iraqi assertions that they had no weapons of mass destruction as well as US Secretary of State Colin Powell's counterclaims. The other news agencies only reported Powell's side and coded his statement with varying degrees of reliability, but not in any specific pattern (ibid., 426-37).

Additionally, in a study on China's entry into the WTO, Zhao (2003) found a shift in sourcing patterns. While government officials from around the world were indeed the main sources, their remarks were quite general, so a noticeably increased participation by 'domestic business leaders' and 'pro-market economists in elite universities and research institutions', who could give the specifics, occurred (ibid., 41). This represents 'a significant new development in Chinese journalism', where traditionally the 'experts' would be Party-officials and bureaucrats (ibid., 42), and shows that experts and the PRC government frequently have what Herman calls 'parallel biases' $(1992,115)$. These experts even toed the party line, calling for an end to 'unnecessary' discussion of the 'positive and negative impacts', while the press became 'loyal propagandists' for the representatives of transnational corporations, the representatives of which were given very favourable treatment, indicating a switch from printing communist propaganda to 'transnational corporate propaganda' (Zhao, 2003, 43). However, this is 'not surprising,' as it simply involves a 'switch of the masters the papers serve' (ibid., 44).

\section{Case Study, Hu Jintao in Africa}

In order to further illustrate the effects sourcing can have on news media production a brief example of comparative sourcing will take place. Between 31 January and 8 February 2007, PRC President Hu Jintao made a visit to several African countries in a show of the PRC and Africa's close relations. This was a quite controversial event, for the PRC deals with many 'rogue' governments that Western countries avoid, which has attracted a lot of criticism of the PRC's foreign policy. It is ideal for our sample here due to its basis in both global politics and trade.

All the news stories published during his visit and found when searching for ' $\mathrm{Hu}$ Jintao Africa' in the websites of Xinhua News Agency (ChinaView.cn) and Reuters News Agency (Reuters.com) were collected, giving a total of 54 and 17 stories respectively. The sources used in each story were then counted and sorted by category (see Table 1). It should also be taken into consideration that the results may be imbalanced due to the low number of Reuters stories; however, the 
Xinhua stories were quite similar in content, and examining the results percentages helps alleviate this deficiency.

Table 1: Origin and number of sources, Xinhua and Reuters, 31 Jan. to 8 Feb. 2007

\begin{tabular}{|l|c|c|c|c|}
\hline \multicolumn{1}{|c|}{ Source } & \multicolumn{2}{|c|}{ Xinhua $(N=79)$} & \multicolumn{2}{c|}{ Reuters (N= 41) } \\
\hline Hu Jintao & $\begin{array}{c}\text { \# of times } \\
\text { sourced }\end{array}$ & $\begin{array}{c}\% \text { of } \\
\text { sources }\end{array}$ & $\begin{array}{c}\text { \# of times } \\
\text { sourced }\end{array}$ & $\%$ of sources \\
\hline Other PRC gov't official & 40 & $50.6 \%$ & 10 & $24.4 \%$ \\
\hline $\begin{array}{l}\text { African President or Prime } \\
\text { Minister }\end{array}$ & 5 & $6.3 \%$ & 5 & $12.2 \%$ \\
\hline Other African gov't official & 11 & $22.8 \%$ & 4 & $9.8 \%$ \\
\hline $\begin{array}{l}\text { Total from PRC and non-oppositional } \\
\text { gov't sources }\end{array}$ & 54 & $98.7 \%$ & 25 & $14.9 \%$ \\
\hline African opposition party official & 0 & $0.0 \%$ & 3 & $7.3 \%$ \\
\hline US gov't official & 0 & $0.0 \%$ & 1 & $2.4 \%$ \\
\hline Total from other gov't sources & 0 & $0.0 \%$ & 4 & $9.7 \%$ \\
\hline Non-expert (citizen) & 0 & $0.0 \%$ & 2 & $4.9 \%$ \\
\hline Non-gov't expert & 1 & $1.3 \%$ & 10 & $24.4 \%$ \\
\hline Total from non-governmental sources & $1.3 \%$ & 12 & $29.3 \%$ \\
\hline
\end{tabular}

Every news article published by either agency used at least one governmental source, with Xinhua using almost entirely only PRC government or nonopposition party African governmental sources (98.7 percent). Reuters used a more diverse range of sources, with 70.7 percent being from governmental sources, including 7.3 percent (three sources) from oppositional government officials and critical NGOs, sources not utilized at all by Xinhua, likely due to their questioning of the dominant 'win-win' discourse. This supports the PM's findings that that most sources come from the official sphere. However the complete omission of dissenting opinions in the PRC coverage shows that, for this subject at least, it is far less 'balanced' than Reuters when it comes to issues important to the CCP.

\section{Advertising Filter}

In the PRC, the influence of advertising on media production is closely connected with the creation of the pro-development ideology discussed below. This is not 
without precedent: Herman and Chomsky $(1988,9)$ note that: '[a]dvertisers will want ... to avoid programs ... that interfere with the "buying mood", instead wanting "programs that will lightly entertain and thus fit in with the spirit of the primary purpose of program purchases - the dissemination of a selling message'. The rise in advertising and commercial influence in the PRC media, even at the cost of challenging the CCP's control (e.g. Latham, 2001, 99-102; Zhao, 2008, 7780 ), shows support for this abstract process of maintaining a good buying mood.

Additionally, we can examine more concrete interaction between the advertising and editorial departments, such as Tuchman's revelations about how the business offices of many TV stations 'routinely' intervene 'to obtain newspaper coverage or stories that involved its advertisers' (Tuchman, 2002, 86; see also Tuchman, 1978). This tendency exists in the PRC as well, and has been exacerbated by the recent increase in 'infomercials and advertorials', as well as 'sponsorship and even the selling of editorial rights to businesses' (de Burgh, 2003a, 35). However, the wall between the editorial and advertising departments is much thinner in the PRC, with most media companies not having and not needing such clearly defined divisions.

There is some resistance to these tendencies, however. One major focus of study is on the economic magazine Caijing, and on its highly respected editor $\mathrm{Hu}$ Shuli. This magazine is unique due to its national distribution, 'fringe' status, and ability to report on business corruption at national, provincial and local levels (Li, 2009). Before accepting the job, she made sure there was a very thick wall between the editorial and advertising departments to ensure that business couldn't buy influence and harm the reputation of the periodical (McGregor, 2005, 215). When businesses would call to protest about an unfavourable story, the management could reply that they had no control over the content of the magazine, quite a difference from the other economic journals, where advertisers exert a strong influence (ibid.).

What kept Hu out of trouble with the government and business is their ideological congruence, that they both share the goal of reforming and modernizing the PRC's economy (ibid., 217), and it would certainly be a different story if she was a political reformer or democracy activist. Similarly, this follows the pattern of many successful financial publications around the world, which depend on having trustworthy, accurate, neutral financial and business information in order keep the trust of their audience. If it was a fashion, entertainment or sports magazine, separation of the editorial and advertising departments would not be on the management's agenda. Thus Caijing can serve as a good example of a publication successfully navigating between party and market influence. It is, however, only an exceptional case for media in general, while still providing a good example of the 
range of activity permitted in the PRC when reporters, business and the government have parallel interests.

\section{Flak Filter}

Herman and Chomsky (1988) note that many activist NGOs in the USA have duty to create flak to influence the production of news. These pressure and interest groups have big budgets, a large staff, connections at the highest levels of the government and media, and a mission to control the way that civil society discourse is conducted. Many closely monitor what the major news media say and can, if needed, induce people to participate in letter-writing campaigns or pressure the channel's advertisers to withdraw their support from an offending channel. Such activity is conducted by both the 'left' and the 'right' for a variety of reasons and on a wide range of issues, and is analytically separate from internal corporateor government-generated backlashes to media messages, which take a different form.

Such a civil society structure does not exist in the PRC, which clearly problematizes this filter. There is little concerted domestic interest in creating flak in the way defined in the PM. PRC press rarely covers a wide range of 'controversial' topics due to governmental edicts, and if they do step out of line it is often the government itself who creates flak, usually internally and away from the public's gaze. Additionally, as Shirk (2007, 100-2) notes, the policy makers in the PRC government routinely monitor the internet to gauge public opinion about certain topics, and are then able to use that knowledge to create publicity campaigns to reduce potential unrest. She attributes this to the difference between authoritarian and democratic countries, that '[p]oliticians in democracies rely on public opinion polls with scientifically selected representative samples ... in order to win elections', while in the PRC government policy is a reaction to appease people who post on the internet who are also 'most likely to take the greater risk of participating in, or even organizing, mass protests' (Shirk, 2007, 103). This view perhaps privileges political communication in democracies, but her point is valid. At the same time, the range of issues about which the PRC population feels most strongly, such as the political status of Taiwan, Xinjiang and Tibet, and the conflicted history with Japan, are often issues inflated by the CCP and manipulated in the media for domestic and international political gain, so it seems the government is constantly battling with a beast it created itself.

The heavy reliance on the internet for PRC citizens' flak-generation means there is less reliance on interest and pressure groups, and more on collective efforts of those who are most internet-savvy. One example from spring 2008 shows how the internet was used by the people to create a great amount of flak over comments CNN's Jack Cafferty made, calling the PRC government 'basically the same bunch 
of goons and thugs they've been for the last 50 years' (quoted in Xinhua, 2008). This was also bolstered by protests against CNN in the USA by PRC expatriates, but the element of internet organization within the PRC, tacitly allowed and potentially instigated by the PRC government, shows that the potential for flak creation is there, but is limited by boundaries set by public opinion in general. As the interaction between online public opinion and the media is a two-way process (Zhou and Moy, 2007), this could be considered a form of flak that affects news production. However, counter to this is the view that most online 'citizens and journalists conform to the hegemonic position and line of the Communist Party when called for' (Lagerkvist, 2008, 137), therefore further research on the room for expression in the PRC blogosphere is needed before these flak-producing effects can be more clearly defined.

Additionally, it should be noted that flak generated by foreign NGOs, especially about 'human rights' or 'freedom' issues, are largely ignored within the PRC mediascape, for foreign NGOs have little chance of creating civic unrest in the PRC due to the intense monitoring of the internet mentioned above.

\section{Dominant Ideology Filter}

As Herman and Chomsky's (1988) study was of Cold War-era news media, the dominant ideology in the USA at that time was labelled 'anti-communism'. While this ideology could be seen as a reaction by the news media to the threat of a Big Other constructed by governments to help unify public opinion, ${ }^{3}$ Herman (2000) notes that the ideological base underpinning anti-communism remains. $\mathrm{He}$ characterizes it as 'an almost religious faith in the market, at least amongst the elite, so that regardless of evidence markets are assumed to be benevolent and non-market mechanisms are suspect' (ibid., 65). Since the volume of literature examining ideological bias in the US news media is extensive 4 no room can be given for a review in this study; instead we consider the relationship of ideology to news media in general.

\section{Ideology and News Media}

The conception of 'ideology' in the PM could be considered very similar to the Marxist conception (although Marxist studies in that regard 5 are not cited directly), and not just because the subtitle's reference to 'political economy' would seem to hearken to a Marxist tradition. While the PM it is not framed in Marxist terminology or modes of analysis, it still implies that the economic base of news

\footnotetext{
${ }^{3}$ Examples include the Soviet Union, after 1989 briefly the PRC (see Stone and Xiao, 2007), and after 9/11 by general Islamophobic 'anti-terrorism' and the 'Axis of Evil' (Iran, Iraq and North Korea).

${ }^{4}$ See Z.G. Pan (2003), Wang (1992) and Kim (2000) for instances involving US reporting on the PRC.

${ }^{5}$ Such as Althusser (1970), who considered media as one of the 'ideological state apparatuses' used to maintain elite rule, Gramsci's influential concept of hegemony, or Žižek (1989), for whom ideological forms are psychologically created to help us deal with the contradictions inherent modern capitalism.
} 
media determines news production, and hence the ideological content of news, to such an extent that any activity by the journalists, editors or other actors cannot compare with the influence of capital's institutions.

Separately, Chomsky says that the Liberal-Democratic (from Walter Lippmann) and Marxist-Leninist theories 'are very close in their ideological assumptions' $(2002,15)$, but this is apparently due to the influence on Chomsky of the mythical Lippmann-Dewey 'debates' (Schudson, 2008) and mischaracterizes Lippmann, at least in his later work. A close reading does not show that Lippmann thought that 'only a small elite, the intellectual community ... can understand the common interests' (Chomsky, 2002, 15), but instead that was Lippmann's observation of tendencies in early twentieth-century USA. He in fact warns that 'the opportunities for manipulation open to anyone who understands the [news media system] are plain enough. The creation of consent is ... a very old [art] which was supposed to have died out with the appearance of democracy', but instead it has 'improved enormously' due to scientific and technological advances (Lippmann, 1997 [1921], 158).

It is clear that the theoretical rationalizations behind the respective media systems are quite different, but what about their actualizations? As Herman says, there is a 'huge gap between western pretensions and nominal values, on the one hand, and western interests and policies, on the other' $(1992,46)$, and it could be that most pretensions and nominal values said to be held by the majority of governmental regimes are, in the end, subservient to their respective pragmatic political and corporate interests. In a similar vein, Gerbner $(1964,495)$ notes that:

ideological perspectives ... will be expressed and cultivated ... in the commercial press as well as in the 'party press' [because] the basic ideological and political choices are inherent ... in the total operation of 'news values' and of standards in reporting.

This is reflected in many studies, such as Wang (1992), Akhavan-Majid and Ramaprasad (2000), Reta (2000), Yang (2003), Herman (1992) and the PM itself, which show the importance of national ideological perspectives in news framing practices. He $(2003,202)$ believes that 'societies where the dominant ideology is well-established ... making a profit and tacitly, or even overtly, propagating the official ideology through media products are not inherently contradictory and incompatible ... a steadfast ideological stance may help to garner profits.'

The PM's conception follows this, focusing on the effects of corporate professionalization on journalists, rejecting the round pegs who won't fit into journalism's square hole, as well as the workplace constraints and routines, such as limitations of time and money on finding many sources, the privileging of 
government sources (discussed later), which have been discussed extensively in the literature. However, we first need to examine the nature of the dominant ideology in the PRC before the analysis can proceed to the ways in which that ideology is transmitted.

\section{Dominant Ideology in the PRC}

Kang believes that one of Mao Zedong's great failings was in the lack of 'laying the necessary cultural and ideological foundations for social reconstruction and modernization', in large part due to the anti-ideological nature of the Cultural Revolution, which deeply harmed traditional Chinese culture $(1998,170)$. This, coupled with the sublimation of 'socialist ideals and Marxism ... to economic reforms', has created a cultural black hole, leaving only 'the ideas of modernization and modernity ... of the capitalist West, and lately of global capitalism' to fill its place (ibid., 171). Communist ideology is now a 'ritualized rhetoric that is vague, abstract, ambiguous and convenient for pragmatic political manipulation' (He, 2003, 199), and the 1980s 'Market-Leninism' ideology (Kristof and WuDunn, 1995) has made way for 'a globally based ideology of developmentalism, emphasizing growth to promote social stability and national unity' (Lee et al., 2006, 583) and maintain Communist Party control (Shirk, 2007).

Some have gone so far as to even label the PRC as having a '[n]eoliberal capitalist ideology' (Shi, 2008, 1199), or at least a tendency to switch between 'neoliberalism as exception' and 'exceptions to neoliberalism', based on what and who the government wants to manipulate (Zhao, 2008, 6). Additionally, many observers of the PRC can see a highly developed sense of Chinese nationalism (e.g. He, 2003, 199-201), and the support of nationalism is enforced on news media through the marketplace by audience demand in conjunction with government censors (Lagerkvist, 2008, 135-9; Shirk, 2007, 85).

In this sense, we can see great similarities in the dominant ideologies of the USA and PRC, that is pro-capitalism. The major difference is the existence of dissenting opinions, of varying force and of a certain range, in the USA, while in the PRC any 'growing space for expression' created by new technology and better education have been strictly confined to 'cyberspace and niche publications', which minimizes their reach and limits their impact (Zhao, 2008, 36). The tendency in capitalist societies only to 'accept potentially subversive influences once they are denatured by becoming commodities' (Heilbroner, 1985, 138), giving the appearance of diversity of opinion while limiting its effects, has apparently yet to emerge in the PRC.

\section{Co-option of Intellectuals}

One major point in the PM is about how intellectuals, largely in control of the production and construction of information, in the USA are reined in and 
controlled. This is done by 'putting them on the payroll as consultants, funding their research, and organizing think-tanks that will hire them directly and help disseminate their messages', all in a way to structure the biases in favour of the dominant ideology (Herman and Chomsky, 1988, 13). Intellectuals in the PRC are in a similar situation, although to a different extent. While the distrust of Chinese intellectuals that led to their 'isolation from the population as a whole' by the CCP (Goldman, 1987, 258) ended when it was realized that Western-trained expertise was needed if a successful transition to capitalism was to be achieved, it is hard to say that there is any measure of intellectual freedom in the PRC similar to that in Western countries. Similar monetary and funding control methods are used as in the USA, but the dominance of vigilant CCP members in educational institutions, research bodies and student organizations remains as an additional safeguard.

The effects of this can be seen in statements by PRC intellectuals such as environmental scholar Jing Wenyong, who says that academics 'can't even talk about economic sacrifices' to protect the environment because '[a]bove all, we must have economic development' (quoted in Kristof and WuDunn, 1995, 390). However, this is similar to actions by the US government in the early twenty-first century, such as rejections of global measures to reduce pollution, citing the need to protect industry (see Corn, 2001), suggesting again that the PRC intelligentsia's ideological stance has many similarities with contemporary ideological currents in the USA (Barné, 1999; Chen, 1997; de Burgh, 2003b).

\section{Co-option of Journalists}

While co-opted intellectuals and think-tanks produce information, it is the journalists who interpret, select and then distribute it. In many fast-developing areas in China, for instance Shenzhen, increasing economic stability for journalists caused them to become 'increasingly apolitical and contented with the status quo' (Lee et al., 2006, 600). It is indeed not surprising that journalists would support an ideology that outwardly benefits not only themselves but their families, employers and the rest of the country as well, especially considering that PRC journalists are predominantly middle or upper class and well educated. This support for opening up to the outside world and accepting global capitalism is exemplified by activities such as joining the WTO, because that 'embodie[s] the norm and stands for civilized global community' (Zhao, 2003, 38), and that line is increasingly hard to argue against.

The internalization of 'proper' news values and 'professional intuition' common in the USA (Chomsky, 2002, 114; see also Breed, 1955; Gitlin, 1980) is also prevalent in the PRC (de Burgh, 2003a; 2003b; Pan and Lu, 2003), especially at higher levels. Standardized professional norms are becoming compulsory in the PRC, with many journalists required to 'take a training program in official ideology, media policies and regulations, journalism ethics, communication theory, and related topics' in 
order to get their press credentials (Zhao, 2008, 29). In the USA the debate about journalists as professionals, craftsmen or artists has never been resolved (Deuze, 2005; Hallin, 2000; Tumbler and Prentoulis, 2005), while the PRC has gone further, introducing a professional regulation system closer to 'the self-regulation of the legal, medical and accounting professions in the West' (Zhao, 2008, 29) than any journalism organizations in the USA would dare to go. At the same time, it is not simply through the ideological apparatuses of education and professional organizations that PRC journalists are constrained; the state still relies heavily on repressive apparatuses, such as physical threats and violence by local police against news media professionals (e.g. Zhao, 2008, 43), and long prison terms for activities 'against' the government, activities rarely practised in the USA.

\section{Effects and Limits of Dominant Ideology}

The effects of this on news media discourse in the PRC is readily apparent, even more so than in the USA. For instance, a study of PRC press discourse about China's entry into the WTO reveals a purely pro-development, pro-globalization stance; 'All newspapers hailed the deal as a 'win-win' situation' (Zhao, 2003, 34), while details of the specific contents of the WTO agreements were consistently hidden or buried in inconspicuous parts of the papers (ibid., 35). This repression of factual content 'goes hand in hand with its active role in rallying moralistic support for the deal and serving as a collective agitator and mobilizer, in the Leninist sense, to get China ready for the post-WTO shakeup' (ibid., 36). In addition, the history of the PRC's tumultuous relationship with the WTO's predecessor, GATT (General Agreement on Tariffs and Trade), is also glossed over to make it appear as if it was 'something China had deserved for a long time' (ibid., 34) and that 'there were never ideological differences between China and the global capitalistic economic order' and certainly never a third way (ibid., 38). Zhao concludes that the dominant discourse in the PRC news media is the depoliticization, naturalization and normalization of the WTO, and ... the acceptance of the logic of neo-liberal globalization' (ibid., 37).

However, it must be noted that the pro-development, pro-capitalism ideology is not the only ideological current affecting PRC news media production. In a study of press discourse during the NATO bombings of Kosovo and Serbia in 1999, Yang found that the PRC's media 'upheld the principle of sovereignty' of Serbia over splittist Kosovo, while the American media focused more on 'Europe's security' (2003, 235). The reactions in Chinese media after Kosovo's declaration of independence in 2008 were quite similar, quoting PRC leaders who were 'deeply worried about its severe and negative impact', not only for the 'peace and stability of the Balkan region' but also 'the fundamental norms governing international relations' (Liu, 2008). While the issue of sovereignty is not directly connected to developmentalism or modernization, it is certainly an important theme in the more closely related nationalist rhetoric, especially in regards to the status of Taiwan, 
Xinjiang and Tibet. While this shows a weakness in the PM's conception of the filter being only the 'dominant' ideology present in that country, and a more fluid and dynamic conception of ideology is perhaps needed, it still brings to light the capitalist base of that ideology, reflected in the other four filters covered above.

\section{Conclusion}

My first goal, to analyse the current political economy of the PRC's news media system using the PM's dimensions, showed that, despite the differences (mainly in the ownership structures), the underpinning of both systems by capitalism allows for many commonalities. Areas of greatest similarity, such as a shared procapitalist ideology and its influence on production, the cooption of intellectuals and journalists, the advertising-dependent profit structure, the influence of a small group of elite media agenda setters, and the structural and organizational filters that affect sourcing, show the effects that having a capitalism-based economy could have on any news media system, no matter what its governmental structure. However, the major differences in the systems are also illuminated, such as the intimidation and violence against dissenting journalists and a civil society led by anonymous internet users and a vigilant, reactionary government and mass media, show the unique nature of the media in the PRC. This could also indicate that flak, the only socio-cultural filter in the PM, is based more on culture and historical differences, thus the evolution of these political communication tools in the PRC still deserves greater attention in the future.

It is in the middle, however, that we find a far more interesting area for future research to focus on. The PRC has an ownership structure that, while currently putting limits on the growth of its media units, is going through a transformation in many ways similar to that of the US and UK during the nineteenth and early twentieth centuries, that is, professionalization of journalists, a kind of secularization by apparent de-partisanship, a de-politicization through greater focus on entertainment media, and increasing corporatization of the media units that could eventually force a massive change in the system. Despite these changes, it is clear the CCP is in control and will not let the system expand beyond its grasp for a long time.

My second goal, to test the PM to see it could be used for further research into the political economy of transitioning media systems, showed that such politicaleconomic terms of analysis can be used productively for any capitalist-based news system. Looking at the differences and similarities of the two systems provides a glimpse into the reasons for such divergences and, as discussed above, the potential trajectories on which modern news media systems may be sent under the influence of capitalism. Further comparative research taking the political economic base of a news media system, especially its influence as a hegemonic agent for 
Hearns-Branaman, A Political Economy of News Media...

capitalist ideology, is, in fact, necessary if we are fully to ascertain the impact globalization will have on our world's developing and transitioning countries and their news media systems.

\section{Acknowledgements}

The author would like to thank Prof. Greg Philo, Prof. Roger Woods, Dr Rena Bivens, Dr Katrin Voltmer and Dr Chris Paterson for comments on this study, as well as Prof. Zhang Xiaoke and Dr Andrew Mullen for opportunities to give presentations on aspects of this research.

\section{References}

Akhavan-Majid, R. and J. Ramaprasad (2000) 'Framing Beijing: dominant ideological influences on the American press coverage of the Fourth UN Conference on Women and the NGO Forum', International Communication Gazette 62(1): 45-59.

Althusser, L. (1970 [2001]) 'Ideology and ideological state apparatuses: notes towards an investigation', in Lenin and Philosophy and Other Essays, trans. and ed. B. Brewster, New York: Monthly Review.

Bagdikian, B.H. (2004) The New Media Monopoly, 2nd edn, Boston, MA: Beacon Press.

Barné, G. (1999) In the Red: On Contemporary Chinese Culture, New York: Columbia University Press.

Breed, W. (1955) 'Social control in the newsroom: a functional analysis', Social Forces 33: 326-55.

Chan, J.M. (2003) 'Administrative boundaries and media marketization: a comparative analysis of the newspaper, TV and Internet markets in China', in C.-C. Lee (ed.) Chinese Media, Global Contexts, London: Routledge Curzon.

Chen, F. (1997) 'Order and stability in social transition', China Quarterly 51.

Chomsky, N. (2002) Understanding Power, edited by P.R. Mitchell and J. Schoeffel, New York: New Press.

Conboy, M.D. (2004) Journalism: A Critical History, London: SAGE.

Corn, D. (2001) 'George W. Bush: the un-science guy', 19 June, available at http://www.alternet.org/story/11054/ (accessed 12 August 2007).

Curran, J. (2002) Media and Power, London: Routledge.

Curran, J. and J. Seaton (1985) Power without Responsibility, 2nd edn, London: Methuen.

Curran, J. and J. Seaton (2009) Power without Responsibility, 7th edn, London: Routledge.

de Burgh, H. (2003a) The Chinese Journalist, London: Routledge Curzon.

de Burgh, H. (2003b) 'Kings without crowns? The re-emergence of investigative journalism in China', Media, Culture \& Society 25: 801-20. 
Deuze, M. (2005) 'What is journalism? Professional identity and ideology of journalists reconsidered', Journalism 6(4): 442-64.

Gerbner, G. (1964) 'Ideological perspectives and political tendencies in news reporting', Journalism Quarterly 41(3): 495-508.

Gitlin, T. (1980) The Whole World is Watching, Berkeley: University of California Press.

Goldman, M. (1987) 'The Party and intellectuals', in R. MacFarquhar and J.K. Fairbank (eds.) The Cambridge History of China, vol. 14, Cambridge: Cambridge University Press.

Hallin, D.C. (2000) 'Commercialism and professionalism in the American news media', in J. Curran and M. Gurevitch (eds.) Mass Media and Society, 3rd edn, London: Arnold.

Hallin, D.C. and P. Mancini (2004) Comparing Media Systems, Cambridge: Cambridge University Press.

He, Z. (2003) 'How do the Chinese media reduce organizational incongruence? Bureaucratic capitalism in the name of Communism', in C.-C. Lee (ed.) Chinese Media, Global Contexts, London: Routledge Curzon.

Heilbroner, R.L. (1985) The Nature and Logic of Capitalism, New York: Norton.

Herman, E.S. (1992) Beyond Hypocrisy, Boston, MA: South End Press.

Herman, E.S. (2000) 'The Propaganda Model: a retrospective', Journalism Studies 1(1): 101-11.

Herman, E.S. and N. Chomsky (1988) Manufacturing Consent, New York: Pantheon Books.

Herman, E.S. and R.W. McChesney (1997) The Global Media: The New Missionaries of Corporate Capitalism, London: Cassell.

Horvit, B. (2006) 'International news agencies and the war debate of 2003', International Communication Gazette, 68: 427-47.

Kang, L. (1998) 'Is there an alternative to (capitalist) globalization? The debate about modernity in China', in F. Jameson and M. Miyoshi (eds.) Cultures of Globalization, Durham, NC: Duke University Press.

Kim, S.T. (2000) 'Making a difference: US press coverage of the Kwangju and Tiananmen pro-democracy movements', Journalism and Mass Communication Quarterly 77(1): 22-36.

Kristof, N.D. and S. WuDunn (1995) China Wakes, New York: Vintage.

Lagerkvist, J. (2008) 'Online journalism in China: constrained by politics, spirited by public nationalism', in C. Patterson and D. Domingo (eds.) Making Online News, Oxford: Peter Lang.

Latham, K. (2001) 'Between markets and mandarins: journalists and the rhetorics of transition in Southern China', in B. Moeran (ed.) Asian Media Productions, Richmond: Curzon.

Lee, C.-C. (2000) 'State, capital and media: the case of Taiwan', in J. Curran and M.-J. Park (eds.) De-Westernizing Media Studies, London: Routledge. 
Hearns-Branaman, A Political Economy of News Media...

Lee, C.-C. (2003) 'The global and the national of the Chinese media: discourses, market, technologies and ideology', in C.-C. Lee (ed.) Chinese Media, Global Contexts, London: Routledge.

Lee, C.-C., Z. He and Y. Huang (2006) "'Chinese Party Publicity Inc." conglomerated: the case of the Shenzhen Press Group', Media, Culture \& Society 28(4): 581-602.

Li, Y. (2009) 'Exploring the journalism frontier in China: a case study of Caijing magazine', paper presented at the Creativity and Innovation in Chinese Media conference, University of Westminster, London, UK, 22-3 June.

Liberthal, K. (1995) Governing China, New York: Norton.

Lippmann, W. (1997 [1921]) Public Opinion, New York: Free Press.

Liu, J. (2008) 'Foreign Ministry spokesperson Liu Jianchao's remarks on Kosovo's unilateral declaration of independence', from Ministry of Foreign Affairs of the People's Republic of China, 18 February, available at http://www.chinese-embassy.org.uk/eng/zt/fyrth/t408032.htm (accessed 30 September 2009).

Lynch, D. (1999) After the Propaganda State, Stanford, CA: Stanford University Press.

Ma, E.K.-W. (2000) 'Rethinking media studies: the case of China', in J. Curran and M.-J. Park (eds.) De-Westernizing Media Studies, London: Routledge.

Marwick, A. (2003) British Society since 1945, London: Penguin.

McChesney, R.W. (2004) The Problem of the Media, New York: Monthly Review Press.

McGregor, J. (2005) One Billion Customers, London: Nicholas Brealey.

Pan, Z. (2000) 'Improvising reform activities: the changing reality of journalistic practice in China', in C.-C. Lee (ed.) Power, Money and Media, Evanston, IL: Northwestern University Press.

Pan, Z. and Y. Lu (2003) 'Localizing professionalism: discursive practices in China's media reforms', in C.-C. Lee (ed.) Chinese Media, Global Contexts, London: Routledge Curzon.

Pan, Z.G. (2003) China's Image in the New York Times: Political, Historical and Cultural Factors, Henan: Henan University Press.

Pei, M. (1994) From Reform to Revolution: The Demise of Communism in China and the Soviet Union, Cambridge, MA: Harvard University Presss.

Peter, A. (2009) 'Reporting hot news: how the Shanghai Dongfang Zaobao covered the Sichuan Earthquake', paper presented at the Creativity and Innovation in Chinese Media conference, University of Westminster, London, UK, 22-3 June.

Redl, A. and R. Simons (2002) 'Chinese media - one channel, two systems', in S.H. Donald, M. Keane and Y. Hong (eds.) Media in China, Richmond: Curzon.

Reta, M.C. (2000) 'US media coverage of the 1994 elections in South Africa', International Communication Gazette 62(6): 523-36. 
Schudson, M. (2008) "The "Lippmann-Dewey Debate" and the invention of Walter Lippmann as an anti-democrat 1986-1996', International Journal of Communication 2: 1031-42.

Shi, Y. (2008) 'The rise of China's media supermarket: an appraisal of cultural imperialism's relevance to the Chinese TV industry', International Journal of Communication 2: 1199-225.

Shirk, S. (2007) China: Fragile Superpower, Oxford: Oxford University Press.

Siebert, F.S., T. Peterson and W. Schramm (1956 [2000]) Four Theories of the Press, Stratford, NH: Ayer Company.

Sparks, C. (2008) 'Media systems in transition: Poland, Russia, China', Chinese Journal of Communication 1(1): 7-24.

Sreberny-Mohammadi, A., D. Winseck, J. McKenna and O. Boyd-Barrett (1997) 'Introduction: media in a global context', in A. Sreberny-Mohammadi, D. Winseck, J. McKenna and O. Boyd-Barrett (eds.) Media in Global Context, London: Arnold.

Stone, G.C. and Z. Xiao (2007) 'Anointing a new enemy: the rise of anti-China coverage after the USSR's demise', International Communication Gazette 69(1): 91-108.

Tuchman, G. (1978) Making News, New York: Free Press.

Tuchman, G. (2002) 'The production of news', in K.B. Jensen (ed.) A Handbook of Media and Communications Research, London: Routledge.

Tumbler, H. and M. Prentoulis (2005) 'Journalism and the making of a profession', in H. de Burgh (ed.), Making Journalists, London: Routledge.

Wang, S. (1992) 'Factors influencing cross-national news treatment of a critical national event: a comparative study of six countries' media coverage of the 1989 Chinese student demonstrations', International Communication Gazette 49: 193-214.

Weber, I. (2003) 'Localizing the global: successful strategies for selling television programs to China', International Communication Garette 65(3): 273-90.

Williams, R. (1968) Communications, 2nd edn, Harmondsworth: Penguin.

Xin, H. (2002) 'The Surfer-in-Chief and the would-be kings of content: a short study of sina.com and netease.com', trans. M. Keane, in S.H. Donald, M. Keane and Y. Hong (eds.) Media in China, Richmond: Curzon.

Xinhua News Agency (2008) 'CNN president apologizes for Jack Cafferty's remarks on China', 15 May 2008, available at http://news.xinhuanet.com/english/2008-05/15/content_8178239.htm (accessed 17 May 2008).

Yang, J. (2003) 'Framing the NATO air strikes on Kosovo across countries: comparison of Chinese and US newspaper coverage', Gazette 65(3): 23149.

Zhang, L.L. (2006) 'Behind the "Great Firewall”: Decoding China's internet media policies from the inside', Convergence 12(3): 271-91. 
Hearns-Branaman, A Political Economy of News Media...

Zhao, Y. (1998) Media, Market and Democracy in China, Urbana: University of Illinois Press.

Zhao, Y. (2003) "Enter the world": Neo-liberal globalization, the dream for a strong nation, and Chinese press discourses on the WTO', in C.-C. Lee (ed.) Chinese Media, Global Contexts, London: Routledge.

Zhao, Y. (2008) Communication in China, Lanham, MD: Rowman and Littlefield

Zhou, Y. and P. Moy (2007) 'Parsing framing processes: the interplay between online public opinion and media coverage', Journal of Communication 57(1): 79-98.

Žižek, S. (1989 [2008]) Sublime Object of Ideology, London: Verso. 